\title{
JOGOS, PERFOMANCES E PERFORMATIVIDADES NA ESCOLA: DAS EXPERIÊNCIAS CORPORAIS À PROBLEMATIZAÇÃO DE DISCURSOS*
}

\author{
Paulina Maria Caon ${ }^{1}$
}

RESUMO: Analisando narrativas sobre experiências corporais de professores e estudantes da Educação Básica, discute-se no artigo os jogos, performances e performatividades emergentes nesse contexto. Jogo, performance e performatividade são vistos como modulaçôes de corporalidade que redimensionam nossa experiência no mundo e possibilitam outras abordagens na análise do cotidiano escolar. $\mathrm{O}$ texto se propóe a problematizar categorias recorrentes na análise da escola, sublinhando as possibilidades de reordenamento, suspensão, subversão de papéis e discursos nesse campo de estudo.

Palavras-chave: Corpos. Escola. Experiência. Performance. Etnografia fenomenológica.

\footnotetext{
*Esse texto desenvolve elementos trabalhados na pesquisa de doutorado Desvelando Corpos na Escola - experiências corporais e estéticas no convívio com crianças, adolescentes e professores, e recebeu financiamento do Programa de Doutorado Sanduíche no Exterior (PDSE), da Coordenação de Aperfeiçoamento de Pessoal de Nível Superior (CAPES) para sua realização.

${ }^{1}$ Universidade Federal de Uberlândia, Instituto de Artes - Uberlândia (MG), Brasil. E-mail: paulinamariaus@yahoo.com

DOI: $10.1590 / C C 0101-32622017168673$
} 


\title{
Games, performances and performativities at school: from the body experiences to the questioning of speeches
}

\begin{abstract}
Analyzing narratives on the corporal experiences of teachers and students in Basic Education, this study draws a discussion of the games, performances and emerging performativities in this context. Game, performance and performativity are seen as corporeality modulations which resize our experience in the world and allow other approaches in the analysis of daily school life. The text intends to problematize recurrent categories in analysis about school, highlighting the possibilities of reordering, suspension, role subversion and speeches in this field of study.

Keywords: Bodies. School. Experience. Performance. Phenomenological ethnography.
\end{abstract}

Pequena historieta eloquente do nascimento das primeiras experiências-questóes: era uma vez uma mulher grávida que descobre que seu terceiro bebê será uma menina e diz: "mais uma mulher para sofrer no mundo...". Essa mãe era a sétima filha mulher entre dez filhos, batizada pela irmã mais velha para não "virar bruxa". Trabalhou em "casa de família" desde os 9 anos e a partir dos 14 nas tecelagens Matarazzo no interior de São Paulo. Essa mesma mãe-mulher trabalha como manicure por alguns anos enquanto seu marido estuda para fazer uma faculdade, à qual não tivera acesso antes disso. Simbólica e concretamente, o curso universitário que ele conclui se transforma na ponte para certa mobilidade social que os faz ingressar na classe média ("remediada", como esse pai costumava dizer). A criança ruiva e branca que nasce em 1977 é chamada de Paulina.

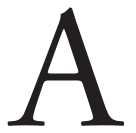

os quatro anos, em São Carlos (interior de São Paulo), eu queria aprender a ler e escrever. Insisti e minha máe, que cursava o magistério àquela época, resolveu me ensinar. Ela escrevia palavras e eu copiava embaixo. Lembro-me da palavra "jacaré" escrita num caderno de caligrafia, meus olhos nela e em seguida meu movimento de 
escrita - os dois braços sobre uma mesa, o quadril sobre uma cadeira, ambas sem forma exata em minha memória corporal. Um flash apenas. Dois anos depois, eu queria acompanhar crianças mais velhas na iniciação ao catecismo. Só podiam participar os "alfabetizados" e, por isso, eu pude "entrar" nessa confraria que inspirava meu desejo - mais para estar junto do grupo de vizinhos do que por alguma fé precoce que me assolasse. Foi o primeiro momento em que a leitura e a escrita me deram um "passe" a espaços e experiências às quais eu não teria acesso. Eu lia muito rápido pequenos textos na novena do bairro para não deixar dúvidas de que realmente "sabia". Talvez essa apropriação precoce de um "código" tenha me feito iniciar a vida escolar com entusiasmo. Eu lia e preenchia os livros didáticos de português, matemática, estudos sociais ou inglês antes mesmo que o ano letivo começasse, o que rendia certa aprovação dos adultos, mas também certa ansiedade ou voracidade no encontro com os outros "mundos" que a escola me apresentava.

Meu convívio com escolas (seus professores, estudantes, diretoras, pátios, parquinhos, carteiras) da Educação Básica se inicia em minha trajetória escolar como estudante, cuja família circulou por algumas cidades de pequeno e médio porte no interior do estado de São Paulo e me levou a conhecer uma parte diversificada do cenário escolar na década de 1980 e 1990 nesse estado.

No início da década de 1990, vivo os anos mais intensos da adolescência antes do ingresso na universidade, cuja narrativa serve aqui como síntese. Estudava em mais um colégio privado confessional nas sétima e oitava séries (nomenclatura da época); pela primeira vez, não me sentia parte daquele grupo social, achava o convívio frio, sem estreitamento de laços de amizade e isso me fazia falta. Ao mesmo tempo, faço um curso livre de teatro na Oficina Cultural (estadual) da cidade. Fico completamente engajada com as proposiçóes do professor, que envolviam improvisaçôes corporais com música, jogos de composição coletiva de histórias e o imaginário que ele compartilhava sobre certo grupo de teatro (Ventoforte/SP), do qual havia feito parte. A ampliação das possibilidades de movimento, por meio das improvisaçóes corporais, o estímulo por esse repertório musical muitas vezes desconhecido até ali era parte de certa atmosfera de encantamento que a experiência teatral trouxe nesse momento. Também a vida em 
grupo, a discussão e a busca de condições para uma ação coletiva e artística na cidade mobilizaram minha atenção, minha vontade de "fazer algo" no mundo.

Em meio à tensão entre a experiência que se dava no colégio particular em São Carlos e a experiência teatral é que peço para sair dessa escola particular. Descubro que há uma escola de segundo grau considerada a melhor escola pública da cidade (argumento que era importante especialmente para meu pai, que se preocupava com a suposta baixa qualidade do ensino na escola pública). Ingresso na Escola Estadual Álvaro Guião e lá se inicia outra etapa de minha percepção da cidade e do mundo. Encontro professores das áreas de História e Geografia que trazem uma visão crítica sobre a história oficial do país; outros professores haviam participado dos movimentos estudantis de São Carlos à época da ditadura e colocavam em debate nossa realidade atual, com vistas a uma formação crítica. Além disso, a diversidade de origens dos estudantes que encontro gera uma rede de amizades e de trocas que marcam minha formação. Há ali filhos de trabalhadores rurais, de professores universitários, de profissionais liberais, de professores da rede escolar. Com eles se constrói uma forte experiência afetiva, política, estética, que culmina na criação de um grêmio estudantil atuante na escola durante os anos do colegial.

A Escola Estadual Álvaro Guião foi a primeira escola normal da cidade de São Carlos, fundada em 1911, e surge, segundo análise de Ailton P. Morila (2005), como parte do projeto republicano de educação no Brasil. Tal projeto tinha pautas claras:

Mas quem era este cidadáo que se queria ter no Brasil? Marta Carvalho [...], analisando o modelo educacional republicano, percebe que ele não se diferencia do projeto imigrantista, pois se a imigração pretendia transplantar uma população que se entendia adequada aos interesses desta nova sociedade, a educação pretendia forjar esta nova sociedade. Portanto, o cidadáo que se queria era branco, europeu, e a sociedade que se queria era estratificada, com direitos e deveres diferenciados segundo a posição no mundo do trabalho. 
Então o que fazer com os libertos, enquanto o embranquecimento da população não acontecia? [...] A permanência do sistema repressivo que manteve a escravidão, mesmo que de forma disfarçada, não era desejada. Era necessário educar os libertos, inculcando os ideais de um cidadão útil, conhecedor de seus deveres. Educá-los era incutir uma ideologia do trabalho [...] colocar o trabalho como valor mais alto da vida em sociedade, o valor mais importante em uma sociedade civilizada. (p. 42)

Desse ponto de vista, o surgimento dessa escola específica é apenas um exemplo dentre muitos outros que constituem o contexto de uma história da instituição escolar no estado de São Paulo e no país. Eu e muitos de meus colegas éramos apenas as versóes modernizadas dos resultantes desse processo: educados/civilizados (por isso, embranquecidos/ europeizados), sendo preparados para uma sociedade estratificada e que cultua o trabalho. Assim, uma síntese possível das ideias que aparecem no fragmento de Morila (2005) seria: a importação de modelos europeus, a ideia de educação como instrução (quase sinônimo de inculcação) e a interface entre educação e trabalho. Não seria de todo equivocado alinhar tais elementos à reflexão de Michel Foucault, segundo o qual o surgimento e a estruturação de certas instituições (familiares, escolares, religiosas, médicas) ao longo dos séculos XVII e XVIII na Europa fazem parte da emergência de uma biopolítica. No texto clássico e exaustivamente citado dos Corpos dóceis (1994), Foucault considera que o objetivo dos sistemas disciplinadores do biopoder consiste no aumento da eficiência (produtividade) e na docilização dos corpos - torná-los simultaneamente úteis e dóceis. A emergência dessa nova forma de poder, segundo o autor, acompanha o surgimento do capitalismo e a necessidade da formatação de corpos úteis.

Apesar da coerência desse raciocínio e de sua aceitação ampla nos diferentes campos de pesquisa em que hoje transito (Teatro, Educação, Antropologia), eu não via minha experiência naquela exata escola em que passei os últimos três anos da Educação Básica dessa maneira. A escola pública tinha sido fundamental para a ampliação de minhas experiências e horizontes de reflexão em relação ao mundo. 
A experiência pessoal vivida em minha trajetória escolar, reunida mais tarde ao questionamento do uso sistemático de categorias histórica e generalizadamente legitimadas na reflexão acadêmica, levoume a propor uma atitude específica ao me aproximar das escolas públicas durante a pesquisa do doutorado e o trabalho atual na universidade federal. Essa atitude mescla "modos de prestar atenção" (CSORDAS, 2011) oriundos de minha experiência como performer e como docente pesquisadora: observadora multifocada e obsessiva nos registros em diário de campo. Busca a abertura do olhar, da escuta, do tato ao que acontece "entre" os corpos; abertura às açóes, sons, olhares que proliferam dentro ou às margens "da aula" propriamente dita, em diálogo com as práticas de observação e escrita da etnografia (GEERTZ, 1989) e da fenomenologia (CSORDAS, 2008; VAN MANEM, 1990).

A partir desse contexto e dessa perspectiva, trago a seguir três narrativas emergentes da pesquisa em campo realizada na Escola de Educação Básica da Universidade Federal de Uberlândia (ESEBA - UFU) e no Centro Educacional Maria de Nazaré durante o doutorado, em que destaco os jogos e traços de performances e performatividades que vislumbro no fluxo das experiências corporais no cotidiano escolar. Busco, após as narrativas, propor uma aproximação entre essas noções e, nas consideraçóes finais, levantar a potencialidade dessa perspectiva no questionamento de discursos e categorias recorrentes na análise da escola.

\section{TECENDO PENSAMENTOS EM EXPERIÊNCIAS CORPORAIS}

\section{PRIMEIRA NARRATIVA (ESCOLA DE EDUCAÇÃO INFANTIL)}

- $\quad$ Parece iniciar-se um tempo livre da turma no pátio da escola. As crianças se espalham em diferentes atividades. Estou sentada no chão de cimento do pátio e se aproxima à minha esquerda um menino desenhando com giz no piso. Longas linhas se delineiam. Às vezes, ele está em pé, dobrado nos quadris, coluna arredondada, alternando passos contínuos que acompanham o riscar do chão com momentos em que 
se interrompe, muda a posição do corpo em relação à linha para continuar. Senta-se, inventa alguma forma dentro do desenho traçado. Ele me mostra: duas longas linhas paralelas, um quase triângulo ao final do traçado. Persigo o "fio" e vejo que é uma só linha que se curvou, dobrando-se sobre si e tornando-se paralela a si mesma. Digo que sempre quis fazer desenhos grandes e que os dele eram muito interessantes. Ele abandona aquele e busca outro espaço. Há crianças por perto, uma delas procura um giz para desenhar também. Ele toma distância propositalmente, não quer dividir seu giz. Uma funcionária tem uma mangueira na mão para molhar um canteiro por perto. Aviso para ele, pensando que a água poderá apagar o desenho. Ele escolhe outro espaço, se desloca em quatro apoios e depois alguns passos em pé; em segui$\mathrm{da}$, pernas rapidamente dobradas para sentar-se novamente. Faz um traçado: dois retângulos desenhados em sequência e o trapézio-telhado em seguida - é uma grande casa no piso mais retângulos arredondados dentro dos outros retângulos compondo janela e porta. O tempo se distende. Eu já fiquei "para trás” no espaço e desenho um pouco também, assim como a outra criança que procurava por um giz. Há burburinho em volta, tentativas de aproximaçáo de outras pessoas, mas sua atenção em relação ao desenho o mantém nele mesmo. Nesse caso, nele mesmo significa também no giz, no piso, na linha, no foco ampliado de seu olhar em relação ao todo que desenha. Fica em pé. Olha o próprio desenho no espaço do piso. Olha em volta outros desenhos. Silencioso.

Observo esse corpo criança entre os corpos, percebendo que eles estão sempre em interação com a matéria do mundo, são corpos às voltas com estímulos microscópicos ou explícitos, provocados a se transformar e provocando transformaçóes em texturas, formas arquitetônicas, objetos. $\mathrm{O}$ corpo se desdobra pelo espaço, como esse menino que desenha com o giz no grande piso do pátio. Nos desdobramentos, há transposiçóes, um gesto corporal que se objetiva em gesto gráfico, que é transposto de um ambiente a outro. Há remodelagem, contami- 
nação do corpo pelo jogo com objetos e dos objetos pela intervenção mais ou menos transformadora dos corpos. Os objetos, a matéria e sua materialidade convidam os corpos a diferentes tipos de jogo entre corpo e espaço. Reciprocamente, ao lidar com eles, com a areia do parque, o giz, o corpo se reelabora, dinamiza-se, guiado pelas proposiçóes claras dessa materialidade.

No caso específico da narrativa compartilhada, relembro Ana Angélica Albano Moreira (1997, p. 8), que trata o desenho infantil numa acepção ampliada, como qualquer dos modos pelos quais uma criança dispóe, organiza seu espaço de jogo com os materiais que tem à mão. Muitos dos estudos sobre o desenho da criança associam seu nascimento aos processos de dominação do próprio corpo em movimento, destacando que os primeiros gestos gráficos são menos representacionais e mais autoinvestigativos. "A criança reinventa todo o processo de aquisição de conhecimento por que passou a humanidade: desde o manejo de instrumentos [...] até conquistas intelectuais, como a capacidade humana de abstrair, corresponder, conceituar" (DERDYK, 1994, p. 111).

Já na linhagem dos estudos sobre a percepção, Gibson (1986) elabora o conceito de affordance ${ }^{1}$ para designar aquilo que o ambiente (superfícies, objetos, animais) oferece (offers) ao corpo. As superfícies, por exemplo, possibilitam o apoio à posição ereta, o suporte para o deslocamento, assim como certos objetos com sua superfície possibilitam ao corpo tomar assento. Sáo elementos fornecidos pelo ambiente ou por seus objetos, e que são experimentados de diferentes maneiras, dependendo do modo como cada um joga com eles, partindo de suas condiçóes corporais. Merleau-Ponty fala em inerência e, por vezes, na simultaneidade das dimensôes corpo-matéria do mundo. Não é apenas o mundo que oferece as oportunidades. Nem são apenas os corpos aqueles que dominam o mundo, o corpo é feito do "estofo mesmo do mundo".

O enigma consiste em meu corpo ser ao mesmo tempo vidente e visível... Ele se vê vidente, ele se toca tocante, é visível e sensível para si mesmo. É um si, não por transparência [...] mas um si por confusão, por narcisismo, inerência daquele que vê ao que ele vê, daquele que toca ao que ele toca, do senciente ao sentido - 
um si que é tomado portanto entre coisas, que tem uma face e um dorso, um passado e um futuro [...] (MERLEAU-PONTY, 2004, p. 17)

Ao observar corpos na escola engajados na produção de um objeto, na interação com esses materiais ou materialidades, essa imbricação no tecido do mundo se intensifica, se torna explícita. Os primeiros momentos de exploração de materialidades do mundo, assim como os momentos de finalização de um objeto/ação artística (uma máscara, um desenho, uma cena) trazem à tona esses modos específicos de prestar atenção (CSORDAS, 2011b), intensidades singulares de corporalidade, em que esse engajamento corpo-matéria-mundo está potencializado. São espécies de jogos que ocorrem nos espaços entre corpo-matéria-mundo, em que as palavras ou as açôes que se efetivam no mundo "[...] são-me arrancados pelo que quero dizer como os meus gestos pelo que quero fazer" (MERLEAU-PONTY, 2004, p. 109). No processo, o sujeito se vê às voltas com a necessidade de se reformular, desvelar ideias e intuiçóes que se apresentam de modo ainda obscuro ou que sequer se apresentam. Os objetos e materialidades do mundo dão contorno ao processo, materializam as regras de jogo com as quais o corpo interage. É nesse percurso que os corpos encontram caminhos para dar forma às experimentaçóes, ideias e intuiçóes pessoais, sem que passem por decisóes lógico-racionais e conscientes constantemente.

Esses jogos do corpo na imbricação com o "estofo do mundo" fazem nascer simultaneamente "um mundo" a ser compartilhado e o pertencimento a "um mundo" que aí estava antes mesmo do nascimento de cada corpo-pessoa, conforme Arendt (1995) e Merleau-Ponty (2004). As interaçôes e imbricaçôes corpo-materialidade emergem como dimensão estruturante das experiências corporais nos tempos-espaços vividos na escola.

No percurso histórico-cultural das sociedades e especialmente do surgimento da noção de instituição escolar, essas affordances e a relevância da imbricação corpo-espaço foram motivos ou objetos de diferentes projetos para os corpos-pessoas, seja como indivíduo, seja como grupos sociais. Estudiosos como Norbert Elias (1993) ou Michel Foucault (1994; 2013), além das linhagens de estudos que se desdo- 
braram de suas contribuiçóes, sublinharam exaustivamente os projetos de disciplinarização ou docilização dos corpos, envolvendo a relação corpo-espaço, corpo-arquitetura. Meus questionamentos, entretanto, intensificados pela observação de crianças, adolescentes e adultos em escolas públicas, visam colocar em primeiro plano alguns ruídos nas circunstâncias em que se manifestam corpos em constituição. Nem sempre de maneira consciente ou deliberada, esses corpos se aproveitam das brechas, abrem fissuras em ordenaçóes e relaçóes nas quais práticas e discursos estavam aparentemente institucionalizados. Os estados de jogo — no entrelaçamento entre corpo-espaço — instauram possibilidades de construção e reconstrução de ordenaçôes (HUIZINGA, 1971), de realidades cotidianas, e experimentaçóes cinéticas e sinestésicas como modo de compreensão (PINEAU, 2010), corporal, do mundo.

\section{SEGUNDA NARRATIVA (ESCOLA DE ENSINO FUNDAMENTAL)}

- As turmas de sétimo ano das artes visuais mostram às turmas de teatro um trabalho em vídeo (stop motion) feito nas aulas. No primeiro horário, a professora e turma demoram a fazer funcionar os aparatos tecnológicos - alguns notebooks da escola, disponíveis para as disciplinas de Artes. Isso gradativamente cria espaço para dispersão. Começam conversas, provocaçóes, pequenos empurróes, cadeiras que se balançam, um urso de pelúcia rosa é manuseado por duas meninas. Em certo ponto da espera, ele já está encaixado com a barriga na cabeça de uma estudante, suas patinhas abraçam a cabeça, o "rosto" do bicho voltado para as costas da estudante. Surgem cantos, pequenos gritos em reposta às provocaçóes de um ou de outro, risadas histéricas a partir do prazer de zombar dos colegas. Um exemplo disso ocorre entre alguns meninos: um deles diz que vai medir a pressão de outro e póe a mão na testa desse outro, como se verificasse a temperatura. Esse é o motivo para uma dessas explosóes de gargalhadas do grupo. Um dos meninos, especificamente, faz uma risada muito aguda e alta, a meu ver, performando mais som e "bagunça" do que a situação realmente propi- 
cia. Um violão dentro de capa circula entre quatro mãos. Ouço de tempo em tempo uma batida, como de tambor. Não é um tambor, mas o violão entre as pernas do próprio dono, que é batido no chão. As conversas em alguns grupos giram em torno dos defeitos corporais ou das escolhas de roupa e cabelo um do outro. Enquanto isso ocorre, uma ou duas pessoas sempre estão concentradas em fazer "rodar" os vídeos nos computadores e projetor. Uma cena se forma: uma linha de três meninos, ocupando três cadeiras, inicia uma discussão. Os dois das pontas do trio se desqualificam mutuamente: a roupa que o outro veste, o tênis, o cabelo, o aparelho dentário. $\mathrm{O}$ menino do meio apenas comenta e "póe lenha na fogueira": "nossa!", "vai deixá?", "nossa... óia o que ele falou...”. Finalmente a aparelhagem funciona. Ainda assim, na plateia, paira a mesma atmosfera de espera dispersa. Alguns dos meninos "brincam" de se bater no rosto, mostrar os punhos. $\mathrm{O}$ professor, em certo ponto, póe as mãos na cabeça de um deles, como se desse um passe; com as mãos "varre" as costas numa linha perpendicular à coluna, do centro para fora, na altura das escápulas, brinca de "clamar" para que "algo das trevas" saia de dentro dele. Há alguma zombaria entre dois estudantes, em torno da produção dos vídeos, respondida com repetidos "Ca'boca!". O menino com o violáo agora o segura por baixo, na parte mais larga, e faz um movimento repetitivo, baixando o braço do violáo em direção à cabeça ou ombro da menina na fila da frente de cadeiras. Começa a trilha sonora de outro vídeo, ele se levanta e usa o violão como apoio no chão para girar e rebolar. Durante cerca de dez minutos ou mais, o garoto da risada histérica continua performando, rindo e comentando qualquer coisa até exagerar de tal modo o som gutural e chegar a tossir. $\mathrm{O}$ som sugere um relincho surdo de cavalo. Ele parece fazer isso para ser visto por alguém, esperando desafiar a (des)ordem já instaurada e talvez uma bronca. A professora de Artes Visuais chama pela atenção do grupo todo, o professor de Teatro senta atrás do menino das risadas e póe a mão nele para tentar "acalmá-lo". 
O cenário de sala de aula se instaura multiplicando encontros. Emergem interaçóes minúsculas, quase invisíveis, enquanto outras ações parecem ser feitas calculadamente para chamar a atenção de um interlocutor, cavando no espaço-tempo uma esfera de enunciação, como diria Zumthor (2007). Outras vezes, a conformação de uma cena está ligada ao enquadramento que meu olhar, ou de outros estudantes, faz para microaçóes, fragmentos de uma realidade múltipla que passa a ocupar nossa atenção por alguns instantes (um dedo lambido "sensualmente" e passado como provocaçáo no braço do colega; uma prova de força entre colegas por trás das costas de outro colega; o violáo com função e sentido seguidamente transformado ao longo do fragmento narrado há pouco). Há momentos em que esse estado corporal de performance do sujeito tem uma intenção clara, propondo fricçôes entre papéis e normas sociais (menino-masculino-sexualidade-homossexualidade) ou entre papéis sociais na instituição escolar especificamente (estudante-professor). Por outro lado, vejo mesclar-se nesse contexto algo mais sutil e cotidiano, como um estado de brincadeira, que aponta para a permanência ou resistência de uma dimensão lúdica nos estudantes que crescem em direção "à vida adulta". Ela me faz lembrar que o jogo ou a criaçáo de uma ordem ficcional paralela (HUIZINGA, 1971) ao fluxo cotidiano das interaçóes escapa, transborda dos momentos criados formalmente pelo professor para a exploração do teatro. Aponta para um impulso humano de criar variaçóes, diferenciar, modular sua corporalidade, desdobrando-se em múltiplas facetas e fragmentos de papéis, que são citados, recriados, atualizados de diferentes modos pelos diferentes estudantes presentes. Sáo oportunidades de viver aquilo que está fora da norma, fora do previsto e dos regulamentos que ordenam a vida cotidiana no tempo-espaço da aula ou no tempo-espaço da escola. Nem sempre o professor percebe esses momentos, nem sempre faz disso ponto de partida para seu trabalho. Algumas vezes atua como parte dessa cena pedindo ou bradando por silêncio, algumas vezes também ele (como no fragmento narrado) parodia seu papel de autoridade ou de controle das corporalidades, fazendo das situaçóes uma citação irônica dos próprios e outros papéis que vivem.

Ao longo do tempo de convivência com essa escola, os corpos em situação de fruição, mesmo os mais aparentemente dispersos, os corpos às margens das propostas da aula, os corpos que ouvem, esperam uma 
atividade, paciente ou impacientemente, significam e dão significado à escola, são parte fundante da vida na escola. Eles não são um resíduo, uma exceção à norma, mas, ao contrário, devolvem ao ambiente essa resposta multissensorial: deriva de movimentos, experiência intercorpórea, fabricação pensada de movimentos-sons incômodos, incontornáveis, que sinalizam sutil ou explicitamente camadas de sentidos sobre o processo de convivência em curso.

Csordas (2011b) sinaliza que esses modos somáticos de atenção são também culturalmente apreendidos, sedimentam-se no tempo e espaço da experiência corporal. Nesse caso, esses modos de prestar atenção levam a um agir avesso à norma. Em sua forma de conduta corporal mais entediada, afetiva ou subversiva, tais açóes trilham seus caminhos de contaminação, reiteração, desdobramento e atualização ao longo da história da instituição escolar, tanto quanto as condutas normativas que tantas vezes são destacadas como presenças dominantes e reiteradas na escola. Os estudantes, ao devolverem ao ambiente essas respostas disruptivas ou cotidianas, afetivas ou indignadas compóem uma contracena marginal ou um metateatro cotidiano, de que John Dawsey (2005) fala, em diálogo com Victor Turner, em que as margens, interrupçóes e antiestruturas são eixos fortes, férteis para a reflexão e compreensão de fatos da vida social.

\section{TERCEIRA NARRATIVA (NA EDUCAÇÃO INFANTIL)}

- Depois do descanso, as crianças são convidadas a ir ao refeitório comer uma fruta e voltam para a sala, onde a professora pede que façam uma roda. Como é cotidiano, as crianças se sentam, levantam, caminham, falam entre si. A professora alonga esse tempo até que a última se sente, pedindo silêncio e dizendo que estamos esperando para ouvir uma música que eu ensinaria. Cantamos a música uma vez, convido o grupo para repetir comigo, penso em convidar para ficar em pé, mas a posição sentada e o "quietinho, prestando atenção" são sublinhados repetidas vezes pelas adultas. Depois de um anticlímax generalizado (para mim e me parece que para elas também), uma das adultas sai para pegar algum material e a outra leva a 
turma até uma pequena arquibancada coberta próxima a um minicampo de futebol da escola para esperarmos a professora que estará com o grupo no período da tarde. Ao voltar, a professora da tarde os leva de volta para a sala. Tenho a primeira sensação de estranhamento em relação à sequência do encontro. Novamente propóe a roda e diz que "vamos esperar" para sair ao pátio e ensaiar a história do beija-flor (em que a canção é usada) junto com outra turma. Em seguida, ela lembra as crianças das brigas ocorridas no período da manhã entre elas e cobra do grupo um "bom comportamento" quando sairmos. Ao chegarmos ao pátio, as duas turmas se encontram e são divididas pelo espaço em vento, fogo e "passarinho". Vento e fogo recebem fitas de papel crepom que são levemente amarradas nos punhos. As professoras das duas turmas colocam o grupo em roda, depois em fila, para então fazer dois círculos concêntricos. Segundo momento de estranhamento. Pergunto-me se elas haviam combinado o ensaio conjunto. Os movimentos propostos às crianças são levantar os braços com as fitas de papel e fazer o círculo girar. Elas trocam ideias sobre como encaminhar a "encenação" da história enquanto tudo acontece. Parecem perdidas; em dúvida sobre o que fazer e me lançam algumas perguntas, com as quais tento dialogar, mas, no fundo, eu não faria nada do modo como estão fazendo e não acho o momento apropriado para conversar. Acabo respondendo evasivamente. As crianças, a essa altura, se dispersam, querem sair da roda, também perdidas. Uma das professoras sai sem que eu perceba e a outra começa a propor cançóes para o grupo. Finalmente, a turma é levada para a sala de teatro, quase como uma punição, sob o argumento de que "não se comportaram bem". Ao chegar à sala, a professora diz que "estamos sem espaço" e pergunta às crianças se elas pensam que merecem ir ao parque. Levo alguns segundos para entender o porquê dessa sequência de açôes e falas da professora desde a chegada à sala. Ela repete várias vezes a pergunta, as crianças ficam entre o silêncio e algumas tentativas de resposta que tendem ao "sim, merecemos ir ao parque”. Cria-se um clima de suspensão, uma espécie 
de cena da punição pelo mau comportamento que parece estar planejadamente direcionado para terminar no parque. Depois de brincarem, lavam pés e mãos para ir tomar lanche. Por fim, são convidados a ir a uma sala para pegar mochila e esperar pelos pais na sala de Teatro. Colocam uma música e uma das professoras performa uma personagem brincalhona, que não tinha aparecido até o momento, enquanto a outra adulta troca as crianças que têm roupa para trocar. Forma-se então nova atmosfera espaço-corporal, em que há barulho, movimento, mas não enxergo muitas conexóes entre crianças ou entre adultos e crianças. $\mathrm{O}$ "estado de espera" parece ser a recorrência no dia.

A insistente troca de espaços ao longo do dia delineia um poder sobre os corpos, conduzidos sem finalidade certa, repetidamente; sublinha a performatividade do papel da professora. Instaura-se uma cena discursiva entre a adulta de cerca de 30 anos e crianças entre 3 e 4 anos, na qual o questionamento reiterado sobre o merecimento do grupo para ir ao parque se torna quase um enigma. As crianças testam respostas possíveis a uma questão que não tem fundamento — não há barganha explícita, visto que é o adulto quem nomeia como mau comportamento um comportamento qualquer. A narrativa em análise me parece exemplar da sequência de pequenos ritos, pequenos exames e interação mediada por papéis que revelam alguns dos mecanismos de construção, fabricação de realidades que também fazem parte da dimensão performativa da educação escolar, conforme revisão de literatura de Pineau (2010).

Observo na narrativa uma encruzilhada entre esse "estado de espera" por algo que nunca acontece, a sensação de uma "aula" sem roteiro prévio, mas também sem abertura para o encontro no tempo presente com as crianças e, por fim, a performatividade da atuação da professora como mediadora assimétrica das possibilidades de deslocamento e ação do grupo no espaço. Emerge um jogo de forças, manifesto pela arbitrariedade na tomada de decisóes e por uma discursividade performativa, no sentido que Butler estabelece: “[...] não como um 'ato' singular e deliberado, antes disso, como a prática reiterativa e referencial mediante a qual o discurso produz os efeitos que nomeia” (2005, p. 18). 


\section{JOGOS, PERFORMANCES E PERFORMATIVIDADES - ENTRELAÇAMENTOS ENTRE OS CONCEITOS}

Ao longo do texto utilizei tais noçóes como chaves para analisar certas açóes ou situaçóes no fluxo das experiências corporais do ser-no-mundo. Tal aproximação entre eles surge durante as experiências em campo na pesquisa do doutorado e tonam-se uma trilha para a continuidade de minha investigação como docente-pesquisadora-artista na universidade.

O “jogo" tem sido categoria importante no estudo da infância ou do desenvolvimento infantil, no estudo das fundações do fenômeno teatral. Assim, também, na Antropologia e Filosofia essa categoria emergiu como marca de um pensamento pautado na observação das experiências humanas de interação entre corpos e entre corpo e mundo.

Huizinga (1971) afirma que o jogo seria a fundação da cultura humana. Por meio dessa experiência de reinvenção temporária de mundos, de ordens paralelas ou específicas, teriam surgido muitos dos modos de ser e estar no mundo, assim como de ferramentas de operação humana nele. George Lakoff e Mark Johnson, em Metáforas da vida cotidiana (2002), analisam os jogos de linguagem (metafórica) como fenômeno enraizado em nossa corporalidade e não apenas como jogos de abstração pura.

A performance como fenômeno do âmbito artístico tem um histórico e diferentes linhagens de estudo, em que os programas ou iniciativas de performers (FABIÃO, 2008) são disparadores de ações individuais e/ou coletivas, não mais centradas na "grande obra" ou no "gênio artístico”. São modos relacionais de criação artística (BOURRIAUD, 2009). Entretanto, nas últimas décadas, surge todo um campo de estudos em torno do conceito de performance como ferramenta de compreensão das interaçóes na vida social, com Erving Goffman (1985), Victor Turner (2003, 2010), Richard Schechner (1985, 2013), por exemplo. Mais recentemente proliferam ainda as abordagens dos estudos culturais, bem como os estudos de gênero, em que se póe em evidência a "performatividade", especialmente a partir da noção de "atos de fala" (BUTLER, 2005; SPIVAK, 2012a,b). Por meio delas se desdobra um modo de análise das interaçóes assimétricas entre professor e alunos, entre colonizador 
e colonizado, entre pesquisadores e "objetos" de estudo. Nesses termos, passa-se a refletir inclusive sobre a performatividade da escrita, mantendo, recriando ou questionando assimetrias. Em todos os casos, vejo raízes na capacidade humana de jogo, de sobreposição, superposição, fricção de camadas de sentido a gestos, condutas, falas, como discursos individuais e coletivos sobre o mundo. Esses sentidos são elaborados por vezes pelo autor do próprio discurso ou pelos seus pares, aqueles que compartilham as situações de atuação/enunciação e as interpretam.

Uma estudante de nono ano sintetizou sua percepção que recai sobre esse tema após uma conversa em subgrupos na sala de aula. Cada subgrupo deveria apresentar o tema escolhido para sua performance em espaços externos da escola. Ela apresenta o tema do seu subgrupo como sendo o tema das "relaçóes" e diz mais ou menos o seguinte: "Somos um camaleão: o modo como trato cada um, interajo com diferentes pessoas..., muda-se o tratamento [aluno-aluno, aluno-professor, aluno-funcionário]. A maneira de cada professor é diferente e os estudantes é que têm que se adaptar”. É interessante perceber a elaboração dela sobre as experiências de interação com diferentes pessoas, em diferentes papéis sociais no contexto escolar. Esse jogo ou encenação construída e inerente às relaçóes também se constitui no aparecimento reiterado do "tédio", do "cansaço" entre os corpos de adolescentes e professores na escola, por exemplo. Torna-se pertinente dizer que nos constituímos como pessoas e como grupos num processo contínuo de performance e/ou jogo, em que nos experimentamos como outros, parodiamos, ironizamos, nos recriamos por meio de nossas experiências intercorpóreas.

Ao destacar os jogos corporais na Escola de Educação Básica da UFU (ESEBA), falei de um estado de brincadeira ou, poderia dizer, de um estado de jogo dos estudantes e resgatei brevemente a relevância que o conceito de jogo tomou como sintetizador de um modo de estar no mundo, de um modo de experimentá-lo que é central na vida humana e no nascimento de uma cultura humana (HUIZINGA, 2010). Também no contexto da Educação Infantil são insistentes as situaçôes de jogo e performance, seja como apropriação e construção de interaçóes regradas (tácita ou explicitamente), seja como jogo de faz de conta, ou como açáo e intensificação de presença. $\mathrm{Na}$ experiência desses jogos, especialmente aqueles que tomam o contorno do "como se" (e, por desdobramento, 
da mimeses), emerge simultaneamente uma dimensão de performance, na acepção já citada de construção de uma esfera de enunciação, conforme Zumthor (2007), ou ainda na citação de açôes e papéis sociais, lembrando a ideia de comportamento restaurado de Schechner (2003). Normalmente tratadas em áreas de debate distintas, vejo similaridade de estatuto entre as práticas denominadas como jogo e como performance no percurso da pesquisa de doutorado.

Os corpos que jogam ou que performam nos exemplos citados atuam sem nenhuma orientação teatral ou artística vindas de um professor ou de qualquer adulto. É a emergência daquele metateatro cotidiano, como propóe Dawsey (2005). Não o teatro proposto pelo professor, mas um teatro que transborda da vida cotidiana, comentando-a, parodiando-a, apropriando-se dela. Essa abertura corporal para o jogo é um dos elementos que fertilizam a experiência escolar, rompendo com a possibilidade de modelagem dos corpos ou reprodução sumária de padrões/ comportamentos impostos (FOUCAULT, 1994; ENGUITA, 1989).

O impulso de reelaboração do mundo por meio do movimento e da ação em jogo/performatividade fundamenta nossos modos de apreender. Ampliar os espaços-tempos de sua exploração e, no caso dos estudantes mais velhos (a partir dos oitavos anos), ampliar os espaçostempos para a reflexão sobre eles parecem ser pistas no caminho de uma educação crítica e estética possível.

Sublinho, contudo, que não se trata, de um lado, de repetir as ideias do "uso" do jogo ou da performance para o ensino de conteúdo, como já questionou Brougère (1990), em que se mecaniza a prática espontânea, buscando um modo "lúdico" ou "agradável” de aprender "o que é realmente necessário". Trata-se, a meu ver, do reconhecimento da relevância das experiências corporais de crianças, adolescentes e adultos que compartilham tempos e espaços na escola. Portanto, trata-se de dar vazão e potencializar as curiosidades, as investigaçóes corporais desses sujeitos, que interagem mutuamente no cotidiano. $\mathrm{O}$ mesmo se passa com a dimensão reflexiva. Não se trata de atribuir sentidos únicos ao que foi vivido, apressando e fixando nomeaçóes ou formas de se fazer arte, teatro, dança como conteúdos que precisam ser "passados" ou "transmitidos". Trata-se de criar espaços para o compartilhamento de sensaçóes, para a experimentação das nomeaçóes. Um desafio nesses contextos é a 
construção de um ambiente suficientemente honesto, provocativo e acolhedor, em que haja oportunidade de se pensar sobre os modos como os sujeitos se organizam ao longo da interação com os outros corpos, com o espaço e, no limite, consigo mesmo.

As práticas que delimito como jogo e performance são mais uma dimensão estruturante da experiência corporal. São modos de apreender o próprio corpo, o entorno e os outros corpos, gerando modulaçóes de corporalidade, temporalidade e espacialidade.

Os jogos, performances e performatividades que aqui aproximo instauram certa suspensão num fluxo cotidiano, intensificando ou esgarçando tempos, espaços e movimentos ao se delinearem. Tais experiências ressignificam as corporalidades dos sujeitos - agregam, sedimentam, reorganizam elementos nelas.

\section{PROBLEMATIZANDO DISCURSOS PREESTABELECIDOS EM RELAÇÃO AO BINÔMIO REPRODUÇÃO-AGÊNCIA}

O panorama multifacetado, mais ou menos conhecido de muitos de nós que passamos por diferentes tipos de escola, não pode ser resumido a uma categoria apenas: corpos modelados? Corpos reprimidos? Corpos submetidos? Corpos subversivos? Como corpo, como pessoa, fugimos à categorização. $\mathrm{O}$ nível de plasticidade, interação, reação a situações é diverso, por isso não acho possível aderir sem ressalvas às teorias em que a possibilidade de improvisação e agência dos sujeitos se conforma apenas ao interior das regras preexistentes no sistema, como em Bourdieu (1991). A ação inesperada, o ruído, o sorriso afetivo, a poesia, a exacerbação de si convivem de modo náo táo previsível quanto pode parecer. A repetição dos olhares para os celulares, dos tênis, crocs, rasteirinhas, marcas de roupas dão notícias, sim, de uma sociedade pautada na hiperestimulação do visual e do consumo. A repetição do sacro apoiado na cadeira, do tédio, das formas "comuns" de comportamento ou reação diante "da" escola ou de um professor propagam também a situação de uma cultura familiar, escolar, social em que se inserem essas pessoas e a pesquisadora. Elas são muitas vezes a reiteração, espaçotemporal, de representações e discursos sobre a escola e os corpos que a 
habitam. Entretanto, como pontuei anteriormente, há fissuras; as dissonâncias produzidas por esses corpos ressoam pelo ambiente e desenham sua própria história de reiteração e variação ao longo do tempo por linhas de fuga e rotas inesperadas.

Ao observar os corpos de crianças e adolescentes no contexto escolar, reencontrei em diferentes momentos modos somáticos de atenção e experimentação de si mesmos no mundo que me remeteram às práticas, treinamentos de atores e performers em busca de um estado de presença no presente, de alinhamento consigo e ao mesmo tempo abertura aos outros corpos e ao espaço para construir processos e açóes artísticas. Em várias situaçóes foram os corpos dessas crianças e adolescentes que me ensinaram sobre o entrelaçamento entre presença, abertura e alinhamento.

Com essa percepção não proponho aqui refazer a apologia do "tudo vem da criança" ou do adulto que deveria silenciar e observar a sabedoria inata dos novos. Falo aqui na subversão de vetores unidimensionais no campo da educação: seja do adulto para a criança, seja da criança para o adulto. Falo em reciprocidade e aposto na experiência da diferença como catalisadora no processo de educação. Falo na dialética que se engendra no convívio entre geraçóes, nas assimetrias entre as diferentes trajetórias sociais culturais dos sujeitos envolvidos no processo. Nessas fricções, trancos, prazeres e faíscas que elas geram é que a interação entre os corpos ensina e que cada corpo-pessoa aprende. Parafraseando Merleau-Ponty (2003), é pelo olhar do outro, pelo contato com os outros que sou inteiramente visível e tangível para mim mesmo. Só pela intercorporalidade e intersubjetividade nos constituímos como pessoa.

\section{ÚLTIMAS PALAVRAS}

Ao discutir a potência das noçôes de jogo, performance e performatividade na análise das experiências corporais na escola, encontro o texto Cuerpos que importan, de Judith Butler (2005). Ele possibilita ressituar um aspecto da problemática com a qual lido: a reiteração exacerbada das representaçóes sobre a escola como instituição cuja finalidade última é a modelagem para constante reprodução de valores de classe ou de um sistema de poder dominante. 
Butler, durante a introdução de seu livro, pondera que a

[...] relação entre cultura e natureza suposta por alguns modelos de "construção" de gênero implica uma cultura ou uma ação do social que age sobre uma natureza, que por sua vez se supóe como uma superfície passiva, exterior ao social e que é, entretanto, sua contrapartida necessária. (2005, p. 21, tradução minha)

Sugiro que, subjacente às representaçôes e reiteraçóes sobre a escola, há certa compreensão de pessoa, pautada no modelo de "construção" que Butler questiona: uma pessoa que é socializada, construída social e culturalmente, vista nesse discurso como superfície passiva "sobre a qual" se imprimem ideias e condutas.

A autora relembra que algumas feministas partiram dessa concepção para ainda cogitar se

[...] o discurso que representa a ação de construção como uma espécie de impressão ou imposição não é na realidade tacitamente masculinista, enquanto a figura da superfície passiva, a espera do ato de penetração mediante o qual se lhe designa significação não é tácita ou — talvez demasiadamente - feminina. (BUTLER, 2005, p. 21)

Sob a ideia da escola como instituiçáo de poder capaz de modelar corpos-pessoas parece correr essa mesma vertente de pensamento, em que os corpos são ainda vistos como matéria inerte em "estado de natureza", uma tábula rasa, cuja superfície é receptiva e "lisa" e "sobre a qual" se impóem padrôes, se "aplicam" procedimentos, ou para a qual se "transmitem" ou se "passam" informaçóes, conhecimentos e normas reguladoras.

Diante dessas outras possibilidades de olhar para a experiência escolar, não vejo possibilidade para a persistência desse discurso sobre a escola e, por desdobramento, sobre o corpo. Também não interessa nesse contexto invisibilizar as incontáveis fissuras, dissonâncias e desarticulaçôes que ocorreram historicamente tanto na instituição escolar desde 
que ela surge, quanto na percepção e reflexão sobre o ser humano, como corporalidade em tensão, em contínua constituição (CAON, 2015).

Talvez, de modo paradoxal, um processo pedagógico na escola poderia ser o encontro entre iguais em inteligência se constituindo como pessoas singulares e mergulhadas na diferença. Ninguém pode prever os redirecionamentos, sínteses, reelaborações que tal encontro proporciona em cada corpo-pessoa participante desses processos. Nas trajetórias que eles delineiam, as reviravoltas, emergências, os solavancos, os rumos inesperados sinalizam instantâneos, flashes de acontecimentos que atestam mistérios. Aparecem e se desvanecem tensões agudas, contradições, dialéticas e communitas - espaços intersticiais, nas margens das estruturas (TURNER, 2010), que suspendem, chacoalham, subvertem papéis, discursos e práticas preestabelecidas.

Gayatri C. Spivak (2012b) fala da necessidade de rearranjar desejos como maneira de praticar a imaginação para uma performance epistemológica. Ela vê nisso uma possível ideia de "educação estética na era da globalizaçáo". Compreendo seu pensamento como um convite à manifestação dos desejos e o exercício contínuo de perceber, manipular e rearranjar as camadas superpostas que conformam categorias (discursos e práticas) que por vezes correm subterraneamente no cotidiano de quem atua na escola.

O campo das artes, as escolas públicas parecem constituir-se hoje como margens, áreas e instituiçóes com poucos recursos materiais por diversos motivos, entre eles sua manifesta "improdutividade" num sistema pautado no trabalho e no consumo. É nesse sentido que vejo hoje nas escolas ou nas universidades a possibilidade de que professores, pesquisadores, estudantes façam dessas margens que habitamos, das desarticulaçóes e precariedades dos sistemas preestabelecidos o próprio espaço de constituição de si mesmos, de reinvenção, fruição e questionamento da performatividade das relaçóes.

\section{REFERÊNCIAS}

ARENDT, H. Entre o passado e o futuro. Sáo Paulo: Perspectiva, 1979.

BOURRIAUD, N. Estética relacional. São Paulo: Martins Fontes, 2009. 
BROUGÈRE, G. Brinquedo e cultura. São Paulo: Cortez, 1990.

BUTLER, J. Cuerpos que importan: sobre los límites materiales y discursivos del "sexo". Buenos Aires: Paidós, 2005.

CABALLERO, I. D. Cenários liminares: teatralidades, performances e política. Uberlândia: EDUFU, 2011.

CAON, P. M. Desvelando corpos na escola - Experiências corporais e estéticas no convívio com crianças, adolescentes e professores. 2015, 290f. Tese (Doutorado em Artes Cênicas) - Escola de Comunicaçóes e Artes. Universidade de São Paulo, São Paulo, 2015.

CSORDAS, T J. Modos somáticos de atención. In: CITRO, S. (org.). Cuerpos plurales. Antropología de y desde los cuerpos. Buenos Aires: Biblos, 2011. p. 83-104.

. Corpo, significado, cura. Porto Alegre: UFRGS, 2008.

DAWSEY, J. C. O teatro dos "boias-frias": repensando a antropologia da performance. Revista Horizontes Antropológicos, Porto Alegre, ano 11, n. 24, p. 15-34, 2005.

DERDYK, E. Formas de pensar o desenho. São Paulo: Scipione, 1994.

ELIAS, N. O processo civilizador. Rio de Janeiro: Jorge Zahar Ed., 1993.

ENGUITA, M. F. A face oculta da escola - Educação e trabalho no capitalismo. Porto Alegre: Artes Médicas, 1989.

FABIÃO, E. Performance e teatro: poéticas e políticas da cena contemporânea. Sala Preta. Revista de Artes Cênicas, Sáo Paulo, n. 8, p. 235-246, 2008.

FOUCAULT, M. Historia de la sexualidad: 1. La voluntad de saber. Buenos Aires: Siglo Veintiuno, 2013.

. Vigiar e punir. Petrópolis: Vozes, 1994.

GIBSON, J. J. The ecological approach to visual perception. New Jersey: Lawrence Erlbaum Associates, 1986.

GOFFMAN, E. A Representação do eu na vida cotidiana. Rio de Janeiro: Vozes, 1985.

HUIZINGA, J. Homo Ludens - o jogo como elemento da cultura. São Paulo: EDUSP e Perspectiva, 1971.

MERLEAU-PONTY, M. O olho e o espirito: seguido de a linguagem indireta e as vozes do silêncio e a dúvida de Cézanne. Sáo Paulo: Cosac\&Naif, 2004. 
. O visivel e o invisivel. São Paulo: Perspectiva, 2003.

. A fenomenologia da percepção. São Paulo: Martins Fontes, 1999.

MOREIRA, A. A. A. O espaço do desenho: a educaçáa do educador. Rio de Janeiro: Loyola, 1997.

MORILA, A. P. Um monumento na avenida: a Escola Normal de São Carlos. Revista HISTEDBR On-line, Campinas, n. 19, p. 40-62, 2005.

PINEAU, E. L. Nos cruzamentos entre a performance e a pedagogia: uma revisão prospectiva. Revista Educação \& Realidade, Porto Alegre, v. 35, n. 2, p. 89-113, 2010.

SCHECHNER, R. O que é performance? O percevejo - Revista de Teatro, Crítica e Estética da UNIRIO, Rio de Janeiro, ano 11, n. 12, p. 25-50, 2003.

SPIVAK, G. C. Pode o subalterno falar? Belo Horizonte: UFMG, 2012a. . An aesthetic education in the era of globalization. Massachusetts: Harvard University Press, 2012b.

TURNER, V. Dewey, Dilthey e drama: um ensaio em antropologia da performance. Cadernos de Campo, São Paulo, ano 14, n. 13, p. 177-186, 2005. . O processo ritual. Petrópolis: Vozes, 2010.

VAN MANEN, M. Researching lived experience: human science for an action sensitive pedagogy. New York: State University of New York Press, 1990.

ZUMTHOR, P. Performance, recepção, leitura. São Paulo: Cosac Naify, 2007.

\section{NOTAS}

1. O termo affordance tem sido utilizado na literatura na língua de origem, pelas dificuldades em alcançar uma traduçáo que abarque de modo preciso o sentido do conceito. Alguns termos já usados como traduções possíveis são: oportunidade, possibilidade, utilidade (no sentido do uso possível). 